\title{
When Seeing and Hearing Do Not Help: Communication Failures in Canadian Films
}

\begin{abstract}
In Canadian cinematography, with its Anglophone and Francophone branches and rich new currents from other cultures, the interest in communication gaps and failures is enormous, although the filmmakers mostly deal with them in global and universal communication contexts. This article examines various aspects of miscommunication through subtitles and focuses on the problems of monolingual people in a foreign-language environment, either in a foreign country (as in Peter Mettler's Tectonic Plates) or in a different part of their native country (the frustration of English-speaking people in Francophone Québec in Denis Villeneuve's "Le Technétium" and Patricia Rozema's Desperanto). In this context, the article explores the unreliability of human sight and hearing and investigates the roles and possibilities of various forms of nonlinguistic, especially visual communication, as presented in Atom Egoyan's En Passant (Passing Through) and Mettler's Tectonic Plates.
\end{abstract}

\section{Key words}

Canadian cinema; Anglophone Canadian films; Québécois films; verbal communication; visual communication; communication gaps; subtitles; translation; signs; Jean Pierre Lefebvre; Peter Mettler; Robert Lepage; Patricia Rozema; Atom Egoyan

The Janus-like double face of Canadian cinematography, with its Anglophone and Francophone profiles, reflects the traditional tensions between English and French culture. To this day the tensions are partially responsible for the limited distribution of Québécois films in English-speaking Canada and Anglophone films in Québec. Even after Canada passed the Multiculturalism Act in 1988, which confirmed multiculturalism "as a fundamental national value," the situation did not 
improve. The English-speaking viewers largely ignore Québécois films and even though the Francophone audience does not have any serious problem with imports from the United States, it is only reluctantly that they let domestic Anglophone films into their minds and hearts; as Kevin Tierney, a renowned Canadian film producer, said in an interview with Matt Hays, "The Canadian [English] film scene cannot get to where Quebec is already. It is not physically, spiritually, culturally, historically, or geographically possible" (Hays 2006). The separation of the two main language branches of Canadian cinematography is further underlined by the fact that many Francophone Canadian films are distributed on DVD without English subtitles. ${ }^{2}$

The misunderstandings and communication gaps that necessarily result from the lack of command of one of the two languages significantly influence the audience's perception of Anglophone Canadian films in Québec and Québécois films in English-speaking Canada. Therefore, when either Anglophone or Francophone Canadian film directors choose communication problems as their theme, even if they abstain from local connotations and consider them in global and universal contexts, they implicitly refer to the linguistic and cultural situation in their country. At the same time it should be noted that among Canadian filmmakers there is an increasing number of what Hamid Naficy calls "diasporic and exilic subjects" (Naficy 2004: 133). Their “Accented Films" (Naficy's term) present ethnic and/or national groups, use their native languages other than English and French, and are perceived as foreign by both Anglophone and Francophone audiences.

According to many psychologists and sociologists, "non-problematic communication" is an oxymoron, even when the communicators speak the same language. For example, Shlomo Giora Shoham, an Israeli sociologist, claims that "effective interpersonal communication is so unlikely that it borders on the impossible" (Shoham 2006: 102) because "no cognitive systems can be alike, or even similar, although the individuals may be exposed to the same source of stimuli" (Shoham 2006: 106). Hearing and seeing do not help, as they are ruled by the mind, which is, however, "attuned to perceive people and other objects selectively" (Shoham 2006: 116). The psychological response to the inevitable communication failure is frustration, which has serious effects on human behavior. The frustration deepens significantly when people try to communicate in a language environment that is not their own, especially if they have no command of the language spoken there or only a severely limited one.

In this article I will first discuss the efficiency of subtitles, one of the major means filmmakers use to bridge inter-lingual misunderstandings. Then I will focus on various possible behavioral reactions to frustration resulting from communication failures, both intropunitive (resignation, nervous breakdown, or suicide), and extrapunitive (violence), and on the role of the senses in the communication process. Finally, I will explore the possibilities of visual communication and other forms of nonlinguistic communication. My sources for this analysis will be four little-known Canadian films from the 1990s which have communication as their main theme: one created by a Québécois, one be- 
ing a joint effort of English- and French-speaking filmmakers, and two made by Anglophone directors.

\section{Subtitles helpful, misleading, and getting wild}

In Canada, subtitles are needed by the majority of monolingual film viewers if they do not want to restrict themselves to watching exclusively Canadian films made in their native language. As the Cybercartographic Atlas of Canadian Cinema confirms, the percentage of bilingual filmgoers is higher only "between Montréal and Toronto" (Caquard et al. 2014: 144) ${ }^{3}$ and even though there are more Frenchspeaking Canadians with at least a passive knowledge of English than Canadian Anglophones with an average command of French, subtitles present substantial help for their perception of a film they see as foreign.

In the present context it is useful to bear in mind that the efficiency of filmmakers' communication is just as limited as anybody else's. If they make an attempt at bridging communication gaps between them and their audiences through subtitles (or dubbing, which replaces the sounds of the original speech with different sounds, foreign to the film, and representing a translation of the speech), ${ }^{4}$ they put themselves into a similar situation to that of the viewers of their films: if they do not speak the target language, they can never be sure whether the subtitles or the dubbing are correct. In spite of that, their position makes them, as far as communication is concerned, superior to the viewers, who receive at best only approximate and at worst incomplete, biased, or simply wrong information about what is said on the screen.

It is becoming increasingly recognized that subtitles, even more than dubbing, instead of reducing the frustration of both viewers and filmmakers, which they were always supposed to do, can actually generate it, or at least contribute considerably to it. Atom Egoyan, a Canadian director with Armenian roots, and Ian G. Balfour, a professor at the Faculty of Liberal Arts and Professional Studies of York University, claim in their introduction to Subtitles: On the Foreignness of Film (2004) that, as a result of cultural differences, every film "is a foreign film, foreign to some audience somewhere - and not simply in terms of language" (21). As multicultural Canada does not have one homogeneous culture, nor does it have two homogeneous cultures, one Anglophone and one Francophone; foreignness in films necessarily "begins at home" (27), as Egoyan and Balfour aptly note.

Watching a film in their native language, the audience perceive the events on the screen both visually and aurally. Through their eyes people watch the actors and the setting, while their ears are able to register dialects or foreign accents of the language and subtle ironies in the speech, as well as marked nuances in intonation. However, if they do not understand the language, their ears only listen to the music of the voices, in which a spark of meaning appears only when a character utters in the foreign language a word that is widely known (for example, bonjour in French), or similar to a word in their native language (although the word 
can have a very different meaning in the other language). A current linguistic research study, for example, at Radboud University Nijmegen, the Netherlands, has proved that people can learn without instruction the meanings of words in a language that they do not speak. In spite of that, viewers of a film in a language they do not know, even though they can watch the gestures accompanying the speech, are still at a loss, as they would need eight occurrences of a word "in sustained speech ... for word recognition to take place" (Gullberg et al. 2010: 11), and that only if the word had two or more syllables (10). Without subtitles, most epic narratives turn, for people who do not speak the language involved, into visual poems accompanied by sounds. With subtitles, stories regain their prominence but the use of seeing and hearing becomes unbalanced: now the process of seeing is doubled, as the viewer must follow the events on the screen and at the same time read the subtitles, while the use of hearing is reduced to a soundtrack that now includes the characters' speech, which suddenly conveys very little meaning and endows relevance only through the written word.

Being aware of the fact formulated, for example, by Louis Giannetti, that "subtitles are distracting and can absorb much of a viewer's energy" (Giannetti 2013: 234), it is necessary to consider other drawbacks of subtitles as well. Amresh Sinha mentions several of them in her contribution to Egoyan and Balfour's volume: because of temporal constraints subtitlers must suppress and omit much information and, like any other translators, "they conform the original to the rules, regulations, idioms, and frame of reference of the target language and its culture" (Sinha 2004: 179). In addition to that, subtitlers sometimes use dialogue lists or shooting scripts as source texts for their translations, not being aware of what is actually said by the actors in the film. When a film in one language marginally uses another language, the makers of dialogue lists often translate the foreign-language sentences into the "major" language of the film. Then the subtitler, without being aware of it, provides a back-translation into the language spoken on the screen. One example shows how misleading, even though hilarious, the outcome might be.

In Jusqu'au coeur (Straight to the Heart, 1969, dir. Jean Pierre Lefebvre), an experimental poetic commentary on the disappointing closure of the revolutionary late 1960s in Québec, the protagonists are played by the then extremely popular singers Robert Charlebois and Claudine Monfette (aka Mouffe), who, as fictional characters, use their own names. In one scene Robert asks for Mouffe's hand in marriage. Even though the film is mostly in French, Robert says in English "Let's stick together," but in the subtitle we simultaneously read, also in English, "Shall we make love?" At such moments Anglophone members of the audience may entertain justified doubts about the quality of the remaining subtitles, but if they cannot understand French they are never able to check it. On the other hand, for the Québécois audience the sudden English sentence sounds suspicious: as Mark M. Smith notes in his Sensory History (2007), any tight community takes foreign sounds as "contaminating" (53). ${ }^{5}$

Another example of a character's speech in English that, due to incorrect interpreting, does not correspond with the French translation subtitled into English in 
"Le Technétium," an episode from the film Cosmos (1996), a joint effort of five young Québécois filmmakers, which was written and directed by Denis Villeneuve, who was later an Academy Award nominee for Incendies (2010). There is a substantial difference, though. While in Lefebvre's Jusqu'au coeur the incorrect back-translation into the original language was non-deliberate, Villeneuve uses it on purpose and introduces the culprit of the misinformation, a TV moderator, Nadia (Audrey Benoit). For a Francophone TV station, she interviews the frontman of a Québécois techno group, the Cyberdogs, who, even though he bears a typical Québécois name, Gilles Ouellette (Stéphane Demers), cannot speak French. Nadia translates Gilles's answers to her questions in a very creative way:

GILLES: Incredible ... it's ... it's a strong word, you know. We've been in New York City for the last three days and ... whew ... been signed to a major label. It's a scoop.

NADIA: A scoop sur Media-TV qui vient de signer un méga contrat avec une méga compagnie. Je vais lui demander si comme moi il est d'accord pour dire que sa musique s'inspire des Wetfuckers ou des Holy Analphases [SUBTITLE: A Media-TV scoop! They've signed a megacontract with a major label. It's a scoop. I'll ask him whether they were influenced by the Wetfuckers or the Holy Analphases]. You think you are making music like the Holy Analphases or something like that?

GILLES [laughing]: No, no, I don't think so ... it's much like ... uhm ... the Beatles ... mixed with some post-punk kind of trance in the environment type of bluegrass, basically that kind of thing...

NADIA: Gilles m'a dit que donc tout à fait il y a des similitudes avec les Analphases [the rest is unintelligible] [SUBTITLE: He agrees they're like the Analphases, but with more hip and pulse.]

Without French subtitles, a Francophone audience could barely find out that the interviewer's translation says the opposite to what the musician declared, even though they are given some clues, both nonverbal and verbal: Gilles's laughter, accompanied by a vigorous negation and his clear pronunciation of "the Beatles," which sounds very different from the name of the (fictitious) group Nadia is obsessed with. On the other hand, the Anglophone viewers recognize that the text in the subtitles is different from what Gilles said but, not understanding Nadia's French, they do not know whether the bias comes from her or from the subtitler, who might have worked only with the French dialogue list, as in the case of Lefebvre's film.

Apart from this, "Le Technétium" explores one more problem connected with the use of subtitles. Both Gilles and Nadia (she is talking extremely fast) use techno jargon, which builds on "hip and pulse" and not on meaning. Especially Nadia talks extremely fast and some of her words are unintelligible; therefore those viewers who are reading the subtitles get more information than those who can understand English and are concentrating fully on the events on the screen. 
Egoyan and Balfour criticize the practice of subtitlers of opening up for film viewers, as unwanted bonuses, even the "spaces that would otherwise be indecipherable" (Egoyan and Balfour 2004: 26), as some words are supposed to stay in the background and not to be heard clearly.

In my third, and last example, the director Patricia Rozema uses subtitles both in the traditional way, as a written translation of what is said on the screen, and on the thematic level, as an important reminder of the radical separation of the world of the characters from the world of the viewers. In her short film Desperanto, or Let Sleeping Girls Lie, the only subtitled episode from Montréal vu par ... (Montreal Sextet, 1991), a joint project of Anglophone and Québécois filmmakers commemorating the $350^{\text {th }}$ anniversary of Montréal in 1992, she shows what happens when the use of subtitles, though not the quality of the translation, is controlled by one of the characters. ${ }^{6}$

Rozema's protagonist is Ann (Sheila McCarthy), a solitary young woman from Toronto, who takes a trip to Montréal, where, pretending to be a dancer, she sneaks into an intellectual party in an art gallery. At the beginning of the film, she watches Denys Arcand's famous Le Déclin de l'empire américain (1986) on a videocassette with English subtitles, but later, when she becomes involved in ordinary party conversations, no subtitles are provided for her, only for those who are watching the film in which she is a character.

Immediately after joining the party, Ann meets the man of her dreams, Étienne, a painter, who is having an argument with his lover Céline, an actress. After Céline departs, Ann tries two French sentences she has painfully learned from her Speedy French, an English-French conversation pocketbook, on Étienne: "Je suis très heureuse de faire votre connaissance" (I am really glad to meet you) and "J'ai folle (sic) envie de toi" (I am absolutely crazy about you). Ann is not aware that the English subtitles, which are supposed to help non-native speakers, such as herself, to understand her textbook statements, significantly distort what she said. Her first French sentence, translated by the subtitler as "I'm happy to meet (sic) your acquaintance" can create an impression that Ann is mistakenly referring to Céline, while the second one, translated as "I'd love to sleep with you too," makes her much more straightforwardly aggressive than she really is.

Gradually, the subtitles begin to reflect Ann's mind and become an integral part of her world. It happens for the first time in the scene in which Ann encounters a communication expert (Robert Lepage), who is attending a conference on the dialogue between humans and machines, but the art of talking to strangers who do not speak his language is obviously outside his field. As Ann's head spins from his fast speech, the sentences, which are mere clusters of meaningless sounds for her, become blurred and echoed and the subtitles get layered one over another and are no longer intelligible. At this moment, Ann enters the world of all non-French-speaking Anglophone viewers, who, as a result of her frustration and confusion, do not receive the expected translation and find themselves in a position similar to hers. 
Later in the film Ann faints and her astral figure is watching a conversation between Étienne and Céline over her lifeless body, stopping it or slowing it down every few seconds, the subtitles at the bottom of the screen included, with a TV remote control to get some time to look up the couple's lines in her small dictionary. In the next scene, however, Ann finally liberates herself, at least in her dream, from the confines of the hostile environment, inhabiting for a while the world of the characters and that of the audience simultaneously. She walks freely among the party guests, toying with subtitles, those tricky "little life lines," as Rozema calls them (Rozema 2004: 66), which are there, at last, for her too. She puts herself in front of them in order to be able to read them (and also hide them from the film viewers), moves them up along the screen so as not to have to bend so much, and when she glimpses the subtitle "how wonderful!" she makes it larger and then mirror-reversed, and finally hides the word "how" in her cleavage, while pouring the letters of "wonderful," one after another, into her glass, together with red wine.

When two paramedics come, Ann recognizes in them Denys Arcand, the director of Le Déclin de l'empire américain, whose photo she saw several hours earlier on the cover of the videocassette, and Geneviève Rioux, the actress who, in the same film, played Camilla, Ann's favorite character. This time Ann does not need subtitles to understand Arcand, as her personal version of "the decline of the American empire" seems to be in English. Still, the ending of the film is ambiguous: in a hallucinatory, musical-like sequence Ann happily dances with the two stars of Québécois cinema on a roof, all three of them slowly overcoming the earth's gravity and vanishing into the air, but the song to which they dance is in French, that is, unintelligible for Ann, and must be subtitled. In addition to this, the English subtitle of the song's refrain, "teach me, oh please, teach me!" that serves as a ground on which all three dancers must stand even in the air is just another ironic reminder of Ann's linguistic incompetence.

As the title of her film, Desperanto, suggests, Rozema connects the theme of the use and abuse of subtitles with a related but more general theme of human despair resulting from failures in communication. Even though she illustrates it through the example of an English-speaking woman in a French-speaking environment, the validity of her observations is universal. Her own characterization of the ordeal of her protagonist - "All her experiences are various runnings into walls" (Rozema 2004: 66) - can be extended to all people, not only to those who must live in a community that uses a language they cannot understand.

\section{Communication failures and their consequences in Tectonic Plates}

The previous part of this article pointed mainly at the hardships of monolingual viewers of foreign-language films and the filmmakers' attempts at overcoming them through subtitles, but also extended the discussion to more general communication problems. 
To show various communication failures and their consequences, I will use one of the most complex Canadian films on this topic so far, Peter Mettler's Tectonic Plates (1992). This unjustly forgotten film is an adaptation of a play for Théâtre Repère by Robert Lepage, the actor, playwright, and director who played the communication expert in Rozema's Desperanto. After touching briefly on the subject of the relationship between language and gender identity, the analysis of the film will examine both the extrapunitive and the intropunitive reactions of its characters to their frustration resulting from abortive attempts at communications, at the same time asking the question of whether a mediocre command of a language, compared to total ignorance of it, can reduce the number of misunderstandings or rather has an opposite effect. It will also discuss the role of the senses, especially sight and hearing, in the communication process.

The central character of Tectonic Plates, around whom the story revolves, is Jacques (Robert Lepage again), a charismatic teacher of art history in Montréal, who suddenly vanishes without a trace. The years-long search of his best friends, a student of arts, Madeleine (Marie Gignac), and a deaf-mute gay librarian, Antoine (Richard Tréchette), does not lead anywhere until Jacques himself sends Antoine a letter from New York, even though without a return address, and Madeleine accidentally hears his voice, reciting Jim Morrison's poems, on the radio. Jacques became Jennifer and, instead of his native French, he uses English. He has his own radio program and even keeps his old (aptly symbolic) surname McMann, and yet his new gender and language identity tear him away completely from his Montréal past.

The bilingual Jennifer/Jacques does not have any problems with understanding language but the change of her/his gender identity makes her/him a paragon of bodily miscommunication: even though $\mathrm{s} / \mathrm{he}$ feels that $\mathrm{s} / \mathrm{he}$ is a woman, $\mathrm{s} / \mathrm{he}$ is imprisoned in a male body. This imbalance, directly or indirectly, widens the gap between her/him and other people, no matter whether they are old friends from her/his Montréal times or new acquaintances.

The most fatal misunderstandings rise during her/his encounters with Kevin (Normand Bissonnette), a young man from Alaska, who won a Berlitz audiotape course in French in a local sweepstake and came to New York to participate in Oprah Winfrey's TV show, followed by dinner in a luxurious restaurant during which twenty Alaskan bachelors were supposed to find girlfriends among single women invited by Oprah to join the audience. Kevin, still without a partner, is the last one left in the restaurant and when Jennifer/Jacques comes for dinner, he falls in love with her/him, not aware that $\mathrm{s} / \mathrm{he}$ is physically a male.

Jennifer/Jacques and Kevin, sitting symbolically at the opposite heads of an extremely long table, lead a conversation in which Kevin wants to put to use his limited command of French. During the conversation it becomes obvious that Kevin's inability to distinguish nuances in pronunciation leads to communication gaps. Where sight would be able to make the necessary language distinctions, the ear is not: 
KEVIN: Mon but c'est de pouvoir comprendre un jour la très belle potrie (sic) française. [SUBTITLE: My goal is one day to understand the beautiful French 'poterie'].

JENNIFER/JACQUES: Pardon, vous avez dit la patrie ou la poterie? [SUBTITLE: Did you say patrie or poterie?]

KEVIN: Poetry.

JENNIFER/JACQUES: Ah, la poesie! Oui ... [SUBTITLE: Oh, poetry!] In French, pottery means ceramics.

The subtitles do not reflect the ambiguity hidden in Kevin's incorrect pronunciation of poesie as "potrie, obviously under the influence of the English "poetry." While Jacques is not sure whether Kevin wanted to say patrie (homeland) or poterie, the subtitler preferred the second option, killing the pun for everyone who has to rely on the visual rendering of the text.

The following part of the conversation revolves around a lexical confusion: Kevin incessantly mixes up "sex" and "gender."

KEVIN: Vous savez ce qui me frustrates ... [SUBTITLE: But, you know, what really frustrates ...]

JENNIFER/JACQUES: Ce qui vous frustre; vous êtes frustré. [NO SUBTITLE]

KEVIN: Ce qui me frustre le plus, c'est euh le sexe! [SUBTITLE: What frustrates me most is ... sex.]

JENNIFER/JACQUES: Ah bon. [SUBTITLE: Oh, really?]

KEVIN: Oui pour ... pour vous les Français, c'est facile le sexe. [SUBTITLE: Yes, for you French people, sex is easy.]

JENNIFER/JACQUES: Vous trouvez? [SUBTITLE: You think so?]

KEVIN: Nous les Anglais on a pas le sexe. [SUBTITLE: We English don't have sex.]

JENNIFER/JACQUES: C'est dommage. [SUBTITLE: What a shame!]

KEVIN: Pourquoi vous dites le café et pas la café, vous dites la table et pas le table? [SUBTITLE: Why is coffee a 'he', not a 'she'? And table 'she', not 'he'?]

JENNIFER/JACQUES: Vous voulez dire le genre! Pas le sexe! [SUBTITLE: You mean gender, not sex!] Sometimes gender can be quite confusing.

The consequences of Kevin's wrong use of "sex" for the grammatical category of gender, for which his poor command of French is only partially responsible (the same difference is also present in English, even though gender is much more weakly grammaticalized there), reach far beyond the field of linguistics. Jennifer/ Jacques clearly explains the difference between the two words for Kevin, but her/ his final remark, uttered in English like an afterthought, suggests how extremely complicated the relationship between these two terms is for her/him. 
Kevin continues to believe his senses, even though they repeatedly betray him. For him, women's clothing and a hairpiece guarantee that the person who wears them is a woman. In his 1967 book The Presence of the Word, Walter J. Ong claims that sight can never lead you beyond the surface, it can "never get to an interior as an interior" (74), and therefore it promotes the role of the other senses, but Kevin's hearing is just as unreliable as his sight. Not only is he unable to grasp the proper pronunciation of French words, but he also considers the sound of a passing subway train to Brooklyn to be an earthquake just because it is accompanied by a mild earth tremor.

In another scene in the film, Kevin admires (in the same restaurant in which the conversation cited above took place) Eugéne Delacroix's picture of George Sand, the French writer known for her independent manners, who adopted a male pseudonym. Kevin, who has no idea who is in the picture, or who it is a painting of, likes the woman because she is at home, sewing and seemingly waiting for her spouse. However, Jennifer/Jacques immediately ruins his impression when $\mathrm{s} /$ he tells him that she is not sewing, but smoking a little cigar while listening to music. The picture, the history of which is told earlier in the film, was originally an unfinished double portrait of Sand sitting on a chair and listening to the piano music of her lover, the Polish composer Frédéric (Fryderyk) Chopin. Later, the picture was cut in two; each of the parts was trimmed further and they were sold as separate items. It is easy to mistake the little cigar in her hand for a needle and, in fact, many art critics share Kevin's opinion that she is really sewing, an opinion that could be backed by what she wrote in a letter to Gustave Flaubert on 30 November 1866: "I like sewing, I delight in washing children; in that I have the tastes of a servant" (Sand 2009: 19). ${ }^{7}$

Kevin finally realizes that every attempt at closer contact with Jennifer/Jacques fails, he cannot rely on his sight and hearing any more, and even his time spent on French textbooks seems to be futile, as his limited knowledge of French is the source of more misunderstandings for him than a zero command of the language would be. Therefore, when Jennifer/Jacques discloses to him that her/his body is not female, it is the proverbial last straw and Kevin's frustration escalates to a strong extrapunitive reaction, culminating in the killing of Jennifer/Jacques by strangling.

There is, however, an alternative opinion that claims that a mediocre command of a language makes a speaker superior even to native speakers. In a 1986 television conversation with four French literary scholars conducted via satellite, Walker Percy, a southern existentialist writer, confirmed his life-long interest in "the pathology of language" and "the phenomenon of the exhaustion of language, the wearing out of the language" (Percy 1993: 168). According to Percy, it is "the dislocations in syntax, or the inappropriateness of the use of the words" (168) that helps to give meaning to words that were long ago reduced to empty shells.

From this point of view, non-native speakers, especially beginners with poor vocabulary, little knowledge of grammar, and grave problems with the pronunciation of foreign sounds, would serve the worn-out languages best. Their mistakes 
would give new, unexpected meanings to the old words, which in turn would help create unexpected situations. Interpersonal communication would once more become an adventure, sometimes dangerous but always fascinating.

The outcome of the encounters between Jennifer/Jacques and Kevin confirms the adventurous and dangerous nature of such communication and Lepage, as the author of the narrative, also shows, through numerous puns, that errors and the misunderstandings resulting from them can be rewarding springs of linguistic comedy. In spite of that, even the fresh language filled with surprises does not diminish the resentment of the communicators and the frightfulness of their possible extrapunitive reactions.

Many years earlier, Jacques's disappearance from Montréal raised an opposite, intropunitive reaction in Madeleine, who loved him as a man and took his departure as her own communication failure. Inspired by Thomas Mann's 1912 novella Der Tod in Venedig (Death in Venice), she leaves for Venice and seeks a romantic silent demise there but, instead, she becomes intimately involved with two people, one woman and one man, and delves into equally frustrating communication with them.

The woman is Constance (Céline Bonnier), the daughter of a Scottish sailor and a Polish ballerina, who took refuge in Venice to escape from their abusive parents. Constance's initial reaction to the frustration resulting from communication failures is just as intropunitive as Madeleine's: resignation, self-affliction through drug abuse, and a death wish. Madeleine finds her immobile in a gondola, accompanies her to the place where she lives, helps her intravenously administer a drug and, after being persuaded by her to take the drug as well, makes love with her. As Madeleine recollects later, she felt an immediate closeness to the young woman, who obviously felt the same resentment as she did. During their intimate moments, Constance utters a few words in Polish - for example, "usta" (mouth) and "serce" (heart). What would have a contaminating effect in a homogeneous non-Polish community has a familiarizing one in a city that is neutral ground for both women. Even Constance's other Polish words and sentences, for example, "czekaj" (wait), directed to her father, suggest emotion and intimacy.

What develops between these women within one day is close to telepathy. Through a drug-induced vision, Madeleine becomes deeply immersed into Constance's life and her nightmares. In her sleep she sees a group of sailors who, under the command of Constance's father, whom she never met, are practicing semaphore signals with flags. The visual layout of the scene suggests the image of Venice as an irreversibly sinking city, a new Atlantis, but also the incorrect pronunciation, by Central European speakers of English, of "thinking" as "sinking." Constance's father appears as a spectral ship's captain who directs his daughter like a sinking ship to doom (even a possibility of incest is visually suggested), while her mother, with a group of dancers, follows. The platform on which both the sailors and the dancers are standing is slowly tipping over and one after another the people end up in the water. The last one above the surface is Constance, but when Madeleine wakes up from the nightmare and finds out that the girl is 
missing, she only discovers her dead body in a canal. From this time Madeleine remembers Constance as her double, who died instead of her.

Another person whom Madeleine meets in Venice is William Rhys (Boyd Clack), a concert pianist specializing in Chopin's music. After their first meeting at an art auction where Delacroix's portrait of George Sand is sold for two million dollars, Rhys invites Madeleine to his concert (which she misses) and, on the following day, he spends the early morning hours with her. Still, years later, in Montréal, not only does he fail to recognize her, but even when reminded of their Italian meeting, he is unable to recollect what happened between them two decades previously.

The clue to this amnesia lies in Rhys's use of his senses: as a pianist he prefers the combination of the aural and the tactile for communication with his listeners and uses his eyes only sporadically in the communication process. Before his concert in Venice he asks his audience: "Now I would like you to close your eyes ... and to imagine that we are in one of Monsieur Pleyel's [the husband of a wellknown Parisian piano maker] salons at the heart of the romantic nineteenth-century Paris amidst the fragrances of exotic flowers..." Hearing with closed eyes can help activate the remaining senses, including olfaction, and turn the human sensory system into a cultural and aesthetic time machine transcending the lives of individuals, including those of the composer and the musician. Only when their sight is "switched off" can the audience spend at least two hours in the past, listening "attentively, religiously" to Chopin's music. The same approach is used in the film by the female psychiatrist who investigates Jennifer/Jacques's problems with gender identity: when she asks her patients to close their eyes and "breathe deeply," she knows that with their eyes closed, they can concentrate better, liberate their imagination more easily, and delve much deeper into their subconscious. Consequentially, they can communicate their past to the psychiatrist in more detail.

The failure of all the characters' attempts at worthwhile language communication, no matter whether the language is French, English, or Polish and what the level of its command is, corresponds with Shoham's skeptical claim that "a mutually meaningful and successful dialogue borders on the miraculous" and the best that we can expect from interpersonal communication is "near failure, semifailures and partial dissonances" (Shoham 2006: 105).

\section{Nonlinguistic sign systems in Tectonic Plates and En Passant}

In the concluding part of my article I will discuss the possibilities of nonlinguistic sign systems, both visual and aural, as alternatives to language in communication. In this context I will also consider communication through art. For my analysis I will again use Mettler's Tectonic Plates but I will also add valuable material from Atom Egoyan's short film En Passant (Passing Through, 1991), which, like Rozema's Desperanto, was a part of the project Montréal vu par... 
The history of the research of communication through art is relatively short; even the recent Encyclopedia of Communication Theory (2009) does not contain entries on visual communication or communication through music. The reason is that neither music nor visual arts are languages, missing as they do, as $\mathrm{Su}$ zanne Langer noted in her classic volume Feeling and Form (1953), "a single, unequivocal reference" (31). Vijai N. Giri, outlining nonverbal communication theories, takes music just as a physical environmental factor (Giri 2009: 693) and, while claiming that "all nonverbal behavior is communication," he uses Judee Burgoon's definition of nonverbal communication that strictly requires "a socially shared coding system" (690) that both visual arts and music lack.

Nonlinguistic sign systems are explored mainly by semioticians, or, if they are related to artistic creativity, by aestheticians. Visual communication and communication through music, besides being aids to better understanding, cannot be divorced from their aesthetic aspects. Dennis Dake, who connects visual communication with creativity, characterizes the method of artistic communication as "visual and intuitive experimentation" (Dake 2005: 4) and points at the validity and complexity of the creative process that focuses simultaneously "on all emerging physical relationships, mental nonmaterial relationships, plus the relationship to personal intentions and goals" (6). What Dake says about visual communication can also be applied to communication through music. Music, too, provides "both part (parsed and detailed) information and whole (holistic and global) information" (Dake 2005: 7), for the decoding of which the synchronized effort of both brain hemispheres is needed (7). The fact that every person responds to a nonlinguistic work of art in a different way increases rather than reduces its communication potential, as the concept of the impossibility of full mutual understanding is already embedded in the transaction.

In Tectonic Plates, Madeleine, in a late reaction to her failed attempts at language communication, returns to painting, an activity she abandoned twenty years earlier. At the end, her pictures are sold at an auction, similar to the one shown earlier in the film in which Delacroix's portrait of George Sand was sold. They are purchased by various prestigious galleries and museums, and it becomes obvious that they successfully tell the whole story of her life, and without words besides those in the titles.

"Self-Portrait with Sir William Rhys" is a recollection of her meeting with the famous pianist in Venice, the meeting that got lost in Rhys's aurally-oriented and, except for musical compositions, very poor memory. "Gondolier Witnesses the Drowning of Ophelia" provides the visual rendering of her complex relationship with Constance, juxtaposing the scene of their first meeting with the image of Constance's dead body in Madeleine's lap. "The Double-Portrait of George Sand and Frédéric Chopin" is conceived as an ultimate bridge over the communication gap caused by those who had destroyed the original Delacroix painting. The last picture at the auction is "J for Jennifer," which, even though its title refers to the new identity of Madeleine's teacher, belongs to a series of her paintings "depicting sailors, ships, and semaphores". This picture, related to Madeleine's 
nightmarish drug-induced vision of Constance, finally confirms that where verbal communication failed, visual communication, both through a past vision and a current work of visual art, at least has a chance to convey a message in all its complexity.

The most interesting lot from the collection is the third picture, "A Spiritualist and the Deaf-Mute," in which, in the auctioneer's words, "we see the artist's tender evocation of the fragility of human communication." It depicts her deafmute friend Antoine and their "conversation," which plays a prominent role in the film. It takes place in the school library and is so lively that the students complain that they are speaking too loudly. At first Madeleine translates from Antoine's sign language, that is, a communication system using the manual-visual modality instead of the oral-aural one (Sandler and Lillo-Martin 2006: 3), but as the conversation becomes more intimate, Antoine grasps Madeleine's neck and lets her speak, through the vibrations of her vocal cords, in a male voice, distinct and loud, not muted any more. His nonverbal communication turns verbal, even though only through another person, but also becomes increasingly violent: during the "dialogue" Madeleine is almost strangled in a similar way as, much later in the film, Jennifer/Jacques by Kevin.

In the opening scene of the film, a parallel is made between the vibrations of the vocal cords and the violent movement from the center of the earth that caused the separation of the continents. The sentence "When you speak... the words... vibrate" seems to have a consoling effect, but the comparison to the shift of tectonic plates makes it sinister, as it suggests what later becomes a certainty: that through the "vibrating" words people become separated, not united. In her painting Madeleine once again juxtaposes two different scenes, even though this time she only participated in one of them. The other scene refers to Jennifer/Jacques's radio talk with a spiritualist, who predicted his interviewer's death. The decision to put a male figure in the place where she herself was supposed to be also creates a parallel to Jennifer/Jacques's change of gender.

Even William Rhys, the concert pianist, is more successful in communication as a performing artist than an ordinary user of language. He communicates through Chopin's music, targeted at general audiences, which is a more than adequate substitute for unsafe and risky verbal communication with individuals. As a bonus, both he and his listeners undergo a strong aesthetic experience.

Walker Percy writes in his non-fiction book, Lost in the Cosmos: The Last Self-Help Book (1983), about the self that transcends the world, including itself, through art or science. In his opinion, the transcendence is worthy even though it is temporary and the reentry into the world is painful, as both the artist and the recipient of art, that is, "the self which receives the sign," find themselves "back in the same fix or worse" (Percy 1984: 121). The idea of transcendence by art nevertheless further confirms the possibility of valuable nonlinguistic communication: artists create signs or networks of them and the recipients, trying to decode them, receive a complex message about the world that is not flattened by the use of language. 
Such artistic signs are not limited to galleries and concert halls but inhabit public spaces and frequently become integral parts of everyday life. Among the art forms that people usually do not perceive as art any more and to which they attribute a higher communicative than aesthetic value are pictograms. At every airport, before passengers get from their flights to the exit, or from the entrance to the boarding gates, they are directed by arrows and multiple visual signs, for example, for luggage and its weight limit, customs, or passport and security checks. A pictogram, that is, a picture representing a word, an idea, or an action, is one of the simplest types of sign, which Charles Peirce in his theory of signs calls "likeness" but is better known as an icon (Peirce 1982: 2:56). ${ }^{8}$ In Egoyan's En Passant (Passing Through) a passenger (Maury Chaykin) lands in Montréal, where he will participate in a convention of pictogram designers. ${ }^{9}$ Throughout the whole film, the passenger does not utter a single word and the viewers have no idea whether he speaks French or not. Not only is his communication exclusively in pictograms, he also thinks in them, and therefore it is impossible to agree with Jonathan Romney, who claims that he is "discovering the city through fresh eyes and ears" (Romney 2003: 86).

While the passenger is at the customs and his luggage is being checked, he can see a man at another counter who has brought into the country more alcohol than is allowed and, not being willing to get rid of it, he is drinking it on the spot. The passenger comments on it at first by a pictogram of a question mark, then by one with a crossed bottle, and finally by another one with two crossed bottles. When he thinks about his hotel, a pictogram with a key, a roof, and a bed appears, and the steps of the passenger's morning hygiene are introduced by pictograms of a shower, a comb, and also of scissors, as he thinks that he should have a haircut. In an early scene he is waving for a taxi and stands exactly like the man on a nearby sign, which leads Romney, who earlier called this film "a semiotic dystopia," to label it as a satire (Romney 2003: 88).

When the passenger wants to take a solitary audio tour through Montréal, he asks for an audio guide by simply showing a pictogram of earphones. However, if he can speak French, he will find out that the female voice in the recording is becoming more and more personal, reminding him among other things of the fact that he is just a tourist. At this time the environment becomes increasingly hostile, as people start bumping into him at a local open-air festival, but even this discomfort and irritation finds its only response in pictograms: a man being pointed at from all four directions by arrows, a man whose head is blowing up, a man constricted by narrowing arcs.

The passenger's communication and thinking are strictly visual and the French female voice from the audio guide is just a pleasant aural background. As the scene at the taxi stand suggests, the passenger himself is turning into an icon. Still, he is also an artist, as his portfolio, carefully examined by a female customs officer at the airport, shows: even though the topics of his pictograms are mundane (danger of falling stones, danger of drowning, danger of electric shock, and an order to keep silent), there is a visual uniqueness as well as an aesthetic quality to them. 
To find out whether nonlinguistic communication is sufficient and can bridge the gaps between speakers of different languages, Egoyan compares the passenger with Rina, the female customs officer who checked the passenger's luggage (Arsinée Khanjian). Rina is a solitary young woman who uses another means of creative visual communication, a more intimate one. Whenever she checks a bag, she takes an artifact from it, be it a visiting card or a luggage tag. At home she looks at her exploits and from memory she draws charcoal pictures of all their owners, finally stapling the corresponding artifacts to the drawings. For her, the people with whom she secretly and indirectly communicates are not just pictograms but unique individuals and the drawings she makes of them are indices, according to Peirce signs "whose relation to their objects consists in a correspondence in fact" (Peirce 1982: 256). Of course, her drawings will never be sold at an auction; paraphrasing Wendy Lee-Hurwitz's formulation, they are visual texts created "by a single producer for one person" (Lee-Hurwitz 2009: 876), that is, herself, not for a general audience. In addition to this, there is nobody to paint and exhibit her face, and she must go to an anonymous street artist to get her own portrait done, a portrait that is not a means of visual communication but a mere routinely produced souvenir, and therefore not an index but an icon. Besides that, it has a much lower aesthetic value than even the passenger's pictograms.

Later, the passenger and the customs officer meet again but while he does not seem to recollect where he met her (his look is similar to that of Rhys, the pianist from Tectonic Plates, who twenty years later did not recognize Madeleine), she gives him a knowing and welcoming smile. Visual communication through indices seems to be more effective on an interpersonal level than that through icons, but it cannot avert the frustrating reentry into the world Percy writes about, as even Rina with her active approach to communication stays alone with her drawings of strangers.

The exploration of communication failures in four films by Canadian filmmakers, both Anglophone and Francophone, suggests the superiority of creative nonlinguistic communication to common verbal communication. Even though the neurologically given limits of human communication are valid even for artists, including film directors and screenwriters, they can at least use signs in ways that do not call for ultimate, non-ambiguous interpretations and enable the viewers to focus on the aesthetic features of their works. As a structural and thematic element in the films, a misunderstanding and the subsequent frustration, even when it results in antisocial behavior, is visually relayed to the audience without major problems and the only serious communication problems are caused by the linguistic incompetence of a portion of the target audience. Subtitles do not seem to eliminate lapses in communication and under certain circumstances they even contribute to them, be it because of a bad translation or simply because they distract the film viewers from the events on the screen.

On the other hand, many characters in the films (most prominently Kevin, Constance, and Madeleine from Tectonic Plates and Ann from Desperanto), 
even though their misunderstandings may look comic to the film viewers, suffer from nightmares that culminate in severe intropunitive or extrapunitive reactions, ranging from apathy to murder. The opinion that an imperfect command of a language is superior to a perfect one, as what is not learnt properly cannot be exhausted, is valid only from the point of view of nonparticipating observers; communicators, whose use of the language is flawed, only find out that their position in communication is worse than that of people who cannot speak the language at all.

The Canadian multicultural environment is extremely suitable for the investigation of communication possibilities and problems and Canadian filmmakers are aware of that. But it is extremely difficult to come to more cheerful conclusions as far as communication is concerned when, on the one hand, people are not able to use their sight and ears properly, and, on the other hand, even good seeing and hearing does not help either film viewers or film characters to understand if they do not know the proper sign system, no matter whether it is verbal or visual.

\section{Notes}

1 The full text of the Multiculturalism Law can be found at the Government of Canada's Justice Laws Website; see $<$ http://laws-lois.justice.gc.ca/eng/acts/C-18.7/page-1.html >

One of the more recent examples is the DVD collection of Denys Arcand's documentaries, Denys Arcand: L'oeuvre documentaire intégrale 1962-1981 (released in 2005 by the National Film Board of Canada in the series La collection memoire).

The Cybercartographic Atlas of Canadian Cinema was developed within a large cartographic research project at Carleton University, Ottawa. To avoid subtitles, some films, including Claude Jutra's Mon oncle Antoine (1971), the Canadian classic, exist in two language versions: in this case the original French and the dubbed English.

Smith does not have in mind only foreign languages or individual words from them but also unfamiliar dialects and accents and even strange noises from the environment that, through the ear, can be perceived as hostile.

On the officially released videocassette, Desperanto is the only episode in the film Montréal $v u$ par... in which both English and French lines are fully subtitled in the other language. The monolingual English-speaking audience can understand two other episodes, Atom Egoyan's En Passant and Léa Pool's Rispondetemi (Answer Me), because they are visual and words do not play an important role in them. The remaining episodes are in non-subtitled French. For Wikipedia, it is a given fact; they even refer to the 1838 portrait of Sand as Sand Sewing. For a useful summation of Peirce's theory see Albert Atkin, "Peirce's Theory of Signs," Stanford Encyclopedia of Philosophy, Summer 2013 Edition, ed. Edward N. Zalta $<$ http:// plato.stanford.edu/archives/sum2013/entries/peirce-semiotics/>. The passenger is nameless in the film but in the credits Egoyan named him Jurgen van Doom, which suggests that he saw the possibility of communication without words as doomed from the very beginning. 


\section{Acknowledgements}

For the transcription of French texts my thanks go to Dorota Bachratá and Zuzana Hildebrandová.

This article was written within the project CZ.1.07/2.3.00/20.068 "Re-presenting of the Past: New Methods of History Interpretation in Arts and Media," co-financed by the European Social Fund and the state budget of the Czech Republic.

\section{References}

Caquard, Sébastien, Daniel Naud, and Benjamin Wright (2014) "Mapping Film Audiences in Multicultural Canada: Examples from the Cybercartographic Atlas of Canadian Cinema." In: Hallam, Julia and Les Roberts (eds.) Locating the Moving Image: New Approaches to Film and Place. Bloomington: Indiana University Press, 130-49.

Dennis Dake (2011) “Aesthetics Theory.” In: Smith, Ken, Sandra Moriarty, Gretchen Barbatsis and Keith Kenney (eds.) Handbook of Visual Communication: Theory, Methods, and Media. New York: Routledge, 3-22.

Egoyan, Atom, dir. (1991) En passant. Montréal vu par... Dir. Denys Arcand, Michel Brault, Atom Egoyan, Jacques Leduc, Léa Pool, and Patricia Rozema. Atlantis Alliance Vivafilm; Cinémaginaire, 2002. VHS.

Egoyan, Atom, and Ian Balfour (2004) Introduction. Subtitles: On the Foreignness of Film. Cambridge, MA: MIT Press; Alphabet City Media, 21-30.

Giannetti, Louis (2013) Understanding Movies. $13^{\text {th }}$ edition. Englewood Cliffs, NJ: Prentice-Hall.

Giri, Vijai N. (2009) Nonverbal Communication Theories." In: Littlejohn, Stephen W. and Karen A. Foss (eds.) Encyclopedia of Communication Theory. Los Angeles: SAGE, 690-94.

Gullberg, Marianne, Leah Roberts, Christine Dimroth, Kim Veroude, and Peter Indefrey (2010) "Adult Language Learning After Minimal Exposure to an Unknown Natural Language." Language Learning 60. Suppl. 2 (December 2010), 5-24.

Hays, Matt (2006) "Producer of the Year: Bon Cop's Kevin Tierney." Playback, 18 Dec 2006. < http://playbackonline.ca/2006/12/18/tierney-20061218/ >.

Langer, Suzanne (1953) Feeling and Form: A Theory of Art Developed from Philosophy in a New Key. New York: Charles Scribner's Sons.

Leeds-Hurwitz, Wendy (2009) “Semiotics and Semiology.” In: Littlejohn, Stephen W. and Karen A. Foss (eds.) Encyclopedia of Communication Theory. Los Angeles: SAGE, 874-76.

Lefebvre, Jean Pierre, dir. (1969) Jusqu'au coeur. National Film Board of Canada, 1969. Film.

Mettler, Peter, dir. (1992) Tectonic Plates. Rhombus Media; Hauer Rawlence Productions; Bullfrog Films, [n.d.]. DVD.

Naficy, Hamid (2004) "Epistolarity and Textuality in Accented Film." Subtitles: On the Foreignness of Film. Cambridge, MA: MIT Press; Alphabet City Media, 131-51.

Ong, Walter J. (1967) The Presence of the Word: Some Prolegomena for Cultural and Religious History. New Haven: Yale University Press.

Peirce, Charles (1982) The Writings of Charles S. Peirce: A Chronological Edition. Ed. Peirce Edition Project. Vol. 2. Bloomington: Indiana University Press.

Percy, Walker (1984) Lost in the Cosmos: The Last Self-Help Book. 1983. New York: Washington Square Press.

Percy, Walker (1993) "Interview on Worldnet." By Claude Richard, Simone Vauthier, Jean Rouberol, and Regis Durand. More Conversations with Walker Percy. Ed. Lewis A. Lawson and Victor A. Kramer. Jackson: University of Mississippi Press, 156-68. 
Romney, Jonathan (2003) Atom Egoyan. London: British Film Institute.

Rozema, Patricia, dir. (1991) Desperanto, or Let Sleeping Girls Lie. Montréal vu par... Dir. Denys Arcand, Michel Brault, Atom Egoyan, Jacques Leduc, Léa Pool, and Patricia Rozema. Atlantis Alliance Vivafilm; Cinémaginaire, 2002. VHS.

Rozema, Patricia (2004) "Little Life Lines in 'Desperanto"” Subtitles: On the Foreignness of Film. Cambridge, MA: MIT Press; Alphabet City Media, 65-67.

Sand, George (2009) Letters of George Sand (in Three Volumes), Vol. III. 1886. Trans. Raphaël Ledos de Beaufort. New York: Cosimo.

Sandler, Wendy and Diane Lillo-Martin (2006) Sign Language and Linguistic Universals. Cambridge: Cambridge University Press.

Shoham, Shlomo Giora (2006) Society of the Absurd: A Sociology of Conflictual Encounters. Second revised and expanded edition. Brighton: Sussex Academic Press.

Sinha, Amresh (2004) "The Use and Abuse of Subtitles." Subtitles: On the Foreignness of Film. Cambridge, MA: MIT Press; Alphabet City Media, 171-90.

Smith, Mark M. (2007) Sensory History. Oxford: Berg.

Villeneuve, Denis, dir. (1996) "Le Technétium." Cosmos. Dir. Jennifer Alleyn, Manon Briand, Marie-Julie Dallaire, Arto Paragamian, André Turpin, and Denis Villeneuve. Max Films Productions. Film.

Marcel Arbeit is Professor in the Department of English and American Studies, Palacký University, Olomouc, Czech Republic. His main fields of research are contemporary southern literature and Canadian cinema. He is the author of a monograph on the novels of Fred Chappell and Cormac McCarthy published in 2006 (in Czech) and the main editor of the three-volume Bibliography of American Literature in Czech Translation (2000). His recent publications focus on Doris Betts, Fred Chappell, Harry Crews, Richard Ford, Lewis Nordan, Flannery O'Connor, Chris Offutt, and Elizabeth Spencer; he co-edited The Mississippi Quarterly special issue on Lewis Nordan (2007, with Thomas Ærvold Bjerre) and The (Un)Popular South (2011, with M. Thomas Inge).

Address: Prof. PhDr. Marcel Arbeit, Dr., Palacký University, Department of English and American Studies, Křížkovského 10, 77180 Olomouc, Czech Republic. [e-mail: marcel.arbeit@upol.cz] 